\title{
Instruktor praktického vyučování ve firmè: role a kompetence
}

\author{
HaNA BARTOŇKová
}

\begin{abstract}
Abstrakt: Prispèvek je zamérén na oblast neformálního vzděláváni dospélých, konkrétnè na oblast dalšiho odborného vzdèláváni. Jeho hlavním cilem je vymezit oblasti a indikátory pro identifikaci kompetenci instruktora praktického vyučováni ve firmè, tedy v kontextu podnikového vzdèláváni. Základni premisou je skutečnost, že instruktor praktického vyučováni neni pedagogickým pracovnikem vintencích zákona o pedagogických pracovnicích (zákon č. 563/2004 Sb.). Je v pracovnéprávním vztahu s organizací, ve které se koná odborný výcvik / odborná praxe. Vede odbornou prípravu žákü, kteři pricházeji na pracoviště vykonávat odborný výcvik nebo odbornou praxi, do jeho pracovni náplně tak spadá rada činnosti souvisejicích s pedagogickým puisobenim. Príspèvek je zpracován jako teoretická studie. V závèru príspèvku jsou na základě zpracováni dostupných zdroju k charakteristice a nároküm kladeným na instruktora praktického vyučováni identifikovány oblasti a indikátory jeho kompetencí. Vyústèním textu je identifikace trú oblasti kompetencí instruktora praktického vyučováni (osobnostni, odborné a pedagogické), príčemž každá je rozpracována do dilčich indikátorü směrujicich do jednotlivých složek kompetence (charakteristiky osobnosti, znalosti, dovednosti/schopnosti). V textu je navržen postup pro méreni uvedených indikátorús využitím škály Hennessyové a Hicksové (2011) a s využitím kategorizace výzkumných postupui podle Lepiče a Kouckého (2012) a Mikkonena a kol. (2017).
\end{abstract}

Klićová slova: neformálni vzděláváni dospělých, dalši odborné vzděláváni, instruktor praktického vyučování, kompetence.

\section{ÚvoD}

Hlavním cílem př́spěvku je vymezit oblasti a indikátory pro identifikaci kompetencí instruktora praktického vyučování ve firmě, tedy v kontextu podnikového vzdělávání. Příspěvek je zpracován jako teoretická studie. Základní metodologický postup je směřován $\mathrm{k}$ vytvoření konceptuálního rámce (Maxwell, 2012; Švaříček,
Šed’ová et al., 2007). Teoretickým východiskem je vymezení dvou klíčových konceptů a jejich kontextualizace. Prvním klíčovým konceptem jsou kompetence a specifikace složek kompetence. Druhým klíčovým konceptem je role instruktora praktického vyučování ve firmě. $\mathrm{Na}$ základě toho bude vytvářen konceptuální rámec. Metodologickým základem $\mathrm{v}$ předloženém příspěvku je tedy formulování výzkumného problému 
(indikátory pro identifikaci kompetencí instruktora praktického vyučování ve firmě), definování klíčových konceptů (kompetence a role instruktora praktického vyučování) a nastínění teoretického a metodického kontextu shrnujícího poznatky o uvedeném tématu. Výstupem předloženého příspěvku je identifikace oblastí a indikátorů kompetencí instruktora praktického vyučování ve firmě.

$\mathrm{K}$ sestavení souboru indikátorů jsou využita uvedená teoretická východiska a zdrojové texty zaměřující se na specifikaci role a činnosti instruktora praktického vyučování. Základní rámec pro identifikaci indikátorů se opírá mj. o texty Starého, Laufkové a kol. (2016), kteří zmiňují proces identifikace indikátorů (zde v kontextu evaluace a hodnocení). V kontextu předložené studie bude proces identifikace indikátorů nastaven následovně:

1. Specifikujeme př́slušnou oblast, ve které identifikaci kompetencí realizujeme - instruktor praktického vyučování (klíčový koncept předložené studie).

2. Specifikujeme (konceptualizujeme) termín kompetence v kontextu, ve kterém identifikaci kompetencí realizujeme.

3. Určíme zdroje pro identifikaci kompetencí - primárně jde o zdrojové texty týkající se role instruktora praktického vyučování a vzdělávání instruktorů praktického vyučování, pracováno je i s kategorizací podle Mikkonena a kol. (2017) a Lepiče a Kouckého (2012) a jejich kategorizací výzkumných postupů („názory pracov- níkư“, „expertní analýzy“ a „šetření u zaměstnavatelü“ $-\mathrm{v}$ tomto př́padě firem i škol).

4.Identifikujeme pozorovatelné oblasti kompetencí (charakteristiky osobnosti, znalosti, dovednosti, schopnosti, event. další jevy, které chceme sledovat).

5. Tvoř́me jednotlivé deskriptory/indikátory, pracujeme s polaritou $\mathrm{v}$ rámci daných kritérií - zde s využitím dimenzí podle Hennessyové a Hicksové (2011).

Př́spěvek se zabývá neformálním dalším odborným vzděláváním instruktorů praktického vyučování. Neformální vzdělávání je ve svém základním pojetí $\mathrm{v}$ prríspěvku vnímáno v souladu $\mathrm{s}$ Memorandem celoživotního učení (A Memorandum, 2000). Další odborné vzdělávání je zde vnímáno v intencích vymezení podle Průchy (2019, s. 14) jako takové, „kdy subjekt po absolvování počátečního odborného vzdělání a př́pravy pokračuje (...) v prohlubování či rozšiřování již nabyté kvalifikace“. Je tak realizováno $\mathrm{v}$ profesním neformálním vzdělávání zaměstnanců. Téma neprímo vstupuje i do oblasti formálního vzdělávání (odborného školství). Nicméně v rámci tohoto př́spěvku jde primárně o specifikaci indikátorů pro identifikaci kompetencí instruktora praktického vyučování ve firmě, tedy v kontextu podnikového vzdělávání. ${ }^{1}$

Základní premisou je skutečnost, že instruktor praktického vyučování není pedagogickým pracovníkem $\mathrm{v}$ intencích zákona o pedagogických pracovnících (zákon č. 563/2004 Sb.). Je v pracovněprávním

${ }^{1}$ Termíny podnikové a firemní vzdělávání či termíny podnik a firma, event. organizace, zde budou vnímány jako synonyma. 
vztahu s organizací, ve které se koná odborný výcvik / odborná praxe. Na pracovišti vede odbornou př́ípravu žáků, kteří tam přicházejí vykonávat odborný výcvik nebo odbornou praxi, a do jeho pracovní náplně tak spadá řada činností souvisejících s pedagogickým působením.

$Z$ výsledků dotazníkového šetření potřeb škol, které proběhlo v projektu P-KAP, vyplynulo, že vzdělávání instruktorů praktického vyučování je jednou z podstatných podmínek a indikátorů kvality spolupráce škol se zaměstnavateli (NUV, 2019). $\mathrm{Na}$ dotaz "Jaká opatření by pomohla vaší škole $\mathrm{k}$ dosažení zvoleného cíle ve spolupráci se zaměstnavateli?" odpovědělo $49 \%$ středních odborných učilišt (SOU) a 36\% středních odborných škol (SOŠ), že je to právě vzdělávání instruktorů, kteř́ zajištují praktickou výuku žákủ na pracovištích. Instruktor nese při praktickém vyučování za žáky odpovědnost, hraje významnou roli při získávání a upevňování pracovních návyků a pomáhá škole při naplňování školního vzdělávacího plánu přesto ho zákon o pedagogických pracovnících nezmiňuje. Pro výkon práce instruktora tedy nejsou legislativně ukotveny žádné pedagogické kvalifikační předpoklady.

\section{INSTRUKTOR PRAKTICKÉHO VYUČOVÁNí}

Role instruktora praktického vyučování je krystalizována mimo jiné z podoby spolupráce firem a škol při realizaci odborného vzdělávání (ČSÚ, 2018a). Jak jsme již zmínili, budeme se v této studii dotýkat i odborného vzdělávání, protože instruktor praktického vyučování se podílí na realizaci odborného vzdělávání ve formálním systému vzdělávání a současně sám může procházet procesem dalšího odborného vzdělávání $\mathrm{v}$ rámci svého profesního neformálního vzdělávání. Chceme-li identifikovat kompetence instruktora praktického vyučování, musíme se nutně zabývat obsahem jeho pracovní činnosti, tudíž tím, které kompetence jsou třeba $\mathrm{k}$ realizaci odborného vzdělávání. $\mathrm{K}$ tomu cílí následující část předložené studie.

Odborným vzděláváním zde máme v souladu s Průchou na mysli „rozsáhlý systém, tj. komplex dílčích segmentů, skupin zúčastněných subjektů, specifických druhů institucí, procesů v nich probíhajících a produkujících určité výsledky a efekty a dále determinant působících na celý tento systém" (Průcha, 2019, s. 11). Toto vymezení totiž přesně vystihuje komplexitu pojetí odborného vzdělávání, která se promítá i do šíŕe nároků a kompetencí potřebných pro výkon role instruktora praktického vyučování.

Proces odborného vzdělávání tvoří pět základních činitelů (Průcha, 2019): 1. aktéŕi systému (tzn. skupiny subjektů, které se účastní odborného vzdělávání nebo ho realizují - zde tedy i instruktor); 2 . podmínky prostředí, v němž systém odborného vzdělávání funguje (tzn. i požadavky zaměstnavatelů - i zde se promítá působení instruktora praktického vyučování); 3. procesy edukace, jimiž se realizuje odborné vzdělávání (tzn. mimo jiné i praktická prríprava a výcvik - i zde je zřejmý význam instruktora praktického vyučování); 4. dále pak výstupy systému, tj. znalosti, 
dovednosti, profesní návyky, postoje atd. (tady se instruktor praktického vyučování přímo podílí na uvedených výstupech); 5. dlouhodobé důsledky projevující se v ekonomických a mimoekonomických př́nosech odborného vzdělávání (instruktor praktického vyučování se podílí svou činností i na této části - uvést můžeme např. práci s motivací žáka během praktického vyučování a další činnosti, ke kterým se ještě dostaneme).

Instruktor praktického vyučování je zaměstnanec podniku, ve kterém probíhá praktické vyučování žáků podle smlouvy o obsahu, rozsahu a podmínkách praktického vyučování. Zmiňovaná smlouva pak konkretizuje úkoly instruktora při řízení učební činnosti žáků, rozsah jeho zapojení do vzdělávacího procesu a náklady s tím související. Samotní zástupci podniků přiznávají, že vybrat vhodného kandidáta na pozici instruktora je někdy obtižné a nemůže ji vykonávat každý (Vencovská, Kaňáková \& Bečváŕová, 2015).

Výběr instruktora, event. jeho neformální profesní vzdělávání, se tak stává klíčovou fází následné realizace praktického vyučování v dané firmě. Instruktor nejen předává odborné dovednosti, ale působí také na formování osobnosti žáka, ovlivňuje jeho vztah $\mathrm{k}$ profesi. Instruktor je tedy jeden ze subjektů procesu odborného vzdělávání. Přesto, jak uvádí Průcha (2019, s. 87), „skupina vzdělavatelů v odborném vzdělávání je výzkumem téměř nezasažena".

Jak jsme již uvedli, teoretickým východiskem předložené studie a podkladem pro identifikaci indikátorů kompetencí in- struktora praktického vyučování je vymezení dvou klíčových konceptů a jejich kontextualizace. Prvním klíčovým konceptem jsou kompetence a specifikace složek kompetence. Druhým klíčovým konceptem je role instruktora praktického vyučování ve firmě. Tomu budou věnovány následující části textu.

\section{KOMPETENCE}

Pro identifikaci kompetencí, resp. jejich oblastí a indikátorů, považujeme za klíčové vymezit termín kompetence a specifikovat jeho obsah a strukturu. Kompetenční prístup zásadním způsobem již několik let ovlivňuje kurikulum počátečního i dalšího vzdělávání (Veteška, 2016). Samotný termín kompetence je pojímán široce a ne zcela konzistentně. $\mathrm{Z}$ hlediska tématu předložené studie je podstatná komplexita pojmu kompetence, se kterou pracuje např. Beneš (2014). Ten do struktury kompetence řadí jak kategorii „vědět“, tak kategorie „umět" a „chtít“. Těžiště tohoto pojetí můžeme nalézt i u Tighta (2003), který konstatuje, že kompetence představuje to, co lidé dokážou, nikoli to, co vědí. Komplexita pojmu kompetence je $\mathrm{v}$ jeho pojetí podpořena specifikací tohoto výroku. Tight uvádí, že je-li kompetence zaměrena na konání, pak musí mít kontext. Zdůrazňuje rovněž, že kompetence je výsledkem, a abychom mohli spolehlivě změrit něčí schopnost konat, musí existovat jasně definované standardy, podle nichž je možné měrit a hodnotit výkon. Kompetence je tak v jeho pojetí míra toho, co někdo dokáže udělat $\mathrm{v}$ daném okamži- 
ku. Toto pojetí se bude prolínat i předloženou studií.

Kompetence instruktora praktického vyučování zde nejsou vnímány pouze jako znalosti či vědomosti. Je s nimi s ohledem na specifika role instruktora praktického vyučování pracováno ve zde uvedeném komplexním pojetí, kompetence se tak skládá z více dílčích složek. Je zde vnímána jako schopnost vykonávat nějakou činnost, umět ji vykonávat, být $\mathrm{v}$ prŕśslušné oblasti kvalifikovaný (Kubeš, Spillerová \& Kurnický, 2004). Kompetence tak můžeme vymezit jako vlastnosti osobnosti, zejména však schopnosti a jim odpovídající vědomosti a dovednosti, které ve svém komplexu umožňují svému nositeli úspěšně vykonávat náročnou činnost $\mathrm{v}$ podmínkách často i nepředvídatelně se měnících situací a obtížných problémů, a tím zastávat více pracovních a sociálních pozic a rolí v průběhu životní cesty/kariéry (Průcha $\&$ Veteška, 2014).

Mezi podstatné charakteristiky kompetencí patř́ rovněž to, že kompetence jsou vždy kontextualizované, obsahují potenciál pro akci a rozvoj a lze je definovat určitým standardem (Tureckiová \& Veteška, 2011). O měřitelnosti a definování určitého standardu v rámci kompetencí hovoří i Spencer a Spencerová ve svém klíčovém díle Competence at Work (1993). Sanghi (2008) vymezuje pět typů kompetencí, $s$ jejichž obdobou zde budeme pracovat: motivy, vlastnosti, self-koncept (tj. sebepojetí/sebehodnocení), znalosti a dovednosti/schopnosti. Poukazuje však na to, že první tři složky kompetence (motivy, vlastnosti a self-koncept) jsou skrytější v rám- ci pozorovatelného chování než zbylé dvě složky (znalosti a dovednosti). Kompetence jsou zde definovány jako komponenty dané pracovní činnosti, které jsou reflektovány v chování pracovníka a pozorovatelné při výkonu dané pracovní činnosti.

Podobně se složkami kompetence pracují např. Luciaová a Lepsinger (1999) či Kubeš et al. (2004). Do anatomie kompetence tak spadají nejen znalosti či schopnosti, ale prredstavíme-li si její strukturu jako hierarchický model, pak její základnu tvoří charakteristiky osobnosti (vlastnosti a rysy osobnosti), které vzděláváním prílišs neovlivníme a které jsou důležité např. již při výběru pracovníka pro danou pozici. Následují složky jako talent, schopnosti, motivy, postoje, hodnoty, které se v průběhu života (a také $\mathrm{v}$ procesu vzdělávání a učení) formují, rozvíjejí, mění. A třetí složkou anatomie kompetence jsou vědomosti, znalosti, dovednosti, zkušenosti, know-how, na jejichž podobu má vzdělávání a učení zásadní vliv. Tyto složky struktury kompetence se poté projevují v chování, resp. v jednání daného pracovníka na pracovišti (Kubeš et al., 2004; Bartoňková, 2010).

$\mathrm{V}$ předložené studii budeme pojem kompetence pojímat $\mathrm{v}$ jeho komplexnosti rozpracovaný do dílčích složek struktury kompetence. Zde uvedené vymezení kompetencí bude sloužit současně jako kritérium pro třídění a analytickou činnost vedoucí $\mathrm{k}$ identifikaci oblastí a indikátorů kompetencí instruktora praktického vyučování (viz tab. 1). Budeme pracovat s rozdělením kompetencí do třri dílčích složek (v souladu s výše 
uvedeným pojetím): 1. charakteristiky osobnosti (tvoří základnu struktury kompetence), 2. znalosti a 3. dovednosti/schopnosti. Představíme-li si strukturu kompetence $\mathrm{v}$ často využívaném modelu pyramidy (např. Sanghi, 2008, Kubeš et al., 2004; Bartoňková, 2010), pak vrchol této pyramidy tvoří pozorovatelné chování/jednání. Při identifikaci indikátorů kompetencí půjde primárně o zde uvedené tř̌i dílčí složky struktury kompetence.

\section{ROLE INSTRUKTORA \\ PRAKTICKÉHO VYUČOVÁNÍ}

Výchozím bodem při určování zdrojů $\mathrm{k}$ identifikaci indikátorů kompetencí instruktorů praktického vyučování budou tři skupiny výzkumných postupů, které rozlišili Lepič a Koucký (2012) při rozsáhlém projektu zaměřeném mimo jiné na postupy uplatňované $\mathrm{v}$ zahraničí ke zjištování kvalifikačních požadavků na pracovníky. Dané rozlišení podle našeho soudu odpovídá charakteru cílové pozice tak, jak ji zde popisujeme. $\mathrm{V}$ textu tedy pracujeme $s$ těmito třemi kategoriemi, které je možné následně rozpracovat ještě podrobněji při využití výstupu předloženého př́spěvku prímo pro identifikaci kompetencí a analýzu vzdělávacích potřeb instruktora praktického vyučování:

- Šetření názorů pracovníků, tzn. v našem prrípadě prrímo instruktorů praktického vyučování, a to na základě identifikovaných indikátorů kompetencí ( $\mathrm{k}$ tomu slouží výstup předloženého prríspěvku v tab. 1).
- Expertní analýzy, tzn. postupy, kdy určitá skupina odborníků charakterizuje nároky pracovního místa pomocí definovaných charakteristik. V kontextu našeho tématu zde hrají roli zejména charakteristiky instruktora praktického vyučování definované $\mathrm{v}$ legislativních normách Ministerstva školství, mládeže a tělovýchovy (MŠMT), Ministerstva průmyslu a obchodu (MPO), v kvalifikačních a hodnotících standardech národní soustavy kvalifikací (NSK), ale i v dalších zdrojích, se kterými budeme pracovat dále $v$ textu a které budou tvořit část podkladu pro identifikaci indikátorů kompetencí instruktora praktického vyučování.

- Požadavky zaměstnavatelů na zaměstnance - zde v kontextu zkoumané cílové skupiny budou vstupovat jak požadavky firmy, tak požadavky školy (např. tematické plány odborného výcviku), protože nároky kladené na instruktora praktického vyučování se krystalizují právě z charakteru a obsahu spolupráce školy a firmy při realizaci praktického vyučování.

Ve zdrojových textech zabývajících se rolí a činností instruktora můžeme vysledovat základní charakteristiku sloužící $\mathrm{k}$ identifikaci indikátorů jeho kompetencí. Instruktor praktického vyučování by měl být odborně zdatný, zkušený pracovník ochotný pracovat $s$ mladými lidmi, trpělivý, chápavý, s nadhledem (Kaňáková, 2019). Jeho role ve výchovně-vzdělávacím procesu v rámci odborného vzdělávání je nezastupitelná. Podílí se na propojení školy a firmy i z hlediska participace na obsa- 
hu vzdělání a celkové strategie. Musí být seznámen s dokumenty školy, event. se svými možnostmi do této oblasti aktivněji vstupovat.

Role instruktora je z hlediska následné možnosti specifikace dílčích indikátorů definována $\mathrm{v}$ materiálu MŠMT (2016). Instruktor je zde charakterizovaný jako „kvalifikovaný, odborně a morálně schopný pracovník poskytovatele $\mathrm{k}$ vedení žáků a $\mathrm{k}$ dozoru praktického vyučování". Instruktor podle tohoto materiálu úzce spolupracuje $s$ pověřeným pedagogickým pracovníkem školy a současně vede nejvýše šest žáků v souladu $s$ ustanovením vyhlášky č. 13/2005 Sb. a č. 374/2006 Sb. Zabezpečuje praktické vyučování pro žáky v souladu se školním vzdělávacím programem a pro studenty $\mathrm{v}$ souladu $s$ akreditovaným programem. Bezprostředně odpovídá za průběh praktického vyučování, který spočívá v osvojování si základních dovedností, činností a návyků, ve zhotovení výrobků, ve výkonu služeb nebo prací, které mají materiální hodnotu. Instruktor ve spolupráci s pověřeným pedagogickým pracovníkem školy provádí klasifikaci žáků. K tomu si vede instruktor deník evidence hod- nocení a docházky žáků. Instruktor se rovněž může podílet na posouzení, zda konkrétní činnost žáků naplňuje definici produktivní činnosti a zda tedy žákovi náleží odměna za produktivní činnost (MŠMT, 2016).

Při snaze charakterizovat podrobně činnost instruktora tak, abychom mohli identifikovat indikátory jeho kompetencí, je třeba pracovat i se skutečností, že žáci, se kterými se instruktor na pracovišti setkává, pocházejí často z různého sociokulturního prostředí, z neúplných či problematických rodin ap. Nemalou roli hraje instruktor také při motivování žáků, kteří často nemají studijní předpoklady a jen obtížně svou vzdělávací dráhu dokončují. ${ }^{2}$ Řada z nich pritom může být manuálně zručná a při dobrém vedení je možné žáky pro studium oboru a jeho zdárné dokončení nadchnout právě na pracovišti. Můžeme $\mathrm{v}$ této souvislosti připomenout Pygmalion fenomén (Rosenthal \& Jacobson, 1992). Jak uvádí realizátoři projektu Pospolu, ${ }^{3}$ žáci instruktora nežrídka považují za vzor a pak samozřejmě také kopírují jeho chování i základní pracovní návyky (NUV, 2015). Velmi podstatná z hlediska identifikace kompetencí instruktora

\footnotetext{
${ }^{2}$ Stojí zde za zmínku výzkum zaměrený na předčasné odchody žáků ze vzdělávání, který pracuje $s$ vývojem dat od roku 2010 do posledního údaje v roce 2019 (Eurostat, 2020). V Česku se počet mladých maximálně se základní školou za posledních deset let zvedl na $6,7 \%$. V roce 2010 to bylo 4,9\%. Tento nárůst je druhý nejvyšší ze všech zemí EU. Nechceme zde dělat zkratkovité závěry směrem k domněnkám, že instruktor může díky vhodné motivaci žáka udržet v systému středního vzdělávání, nicméně na významnost i této složky kompetence instruktora praktického vyučování to spolu s výše uvedenými tvrzeními realizátorů odborného vzdělávání může ukazovat.

${ }^{3}$ Projekt Pospolu byl financován z prostředků Evropského sociálního fondu a probíhal od roku 2012 do roku 2015. Projekt připravilo MŠMT ve spolupráci se zaměstnavatelskými svazy. Realizátorem projektu bylo MŠMT, partnerem projektu byl Národní ústav pro vzdělávání.
} 
praktického vyučování je i složka kompetence týkající se charakterových vlastností osobnosti (viz výše základna anatomie kompetence). Jak uvádějí realizátoři projektu Pospolu: „pro kvalitní práci instruktorů je důležité, aby tito pracovníci byli trpěliví, slušní a aby měli dobrý vztah k mládeži a uplatňovali pedagogický takt. Měli by mít zároveň přirozenou autoritu a respekt žákü“ (tamtéž). V tabulce $1 \mathrm{~s}$ přehledem identifikovaných indikátorů kompetencí čerpáme i z rozhovorů s žáky, kteří popisují a hodnotí instruktora. Z hlediska struktury kompetence spočívá většina charakteristik „dobrého instruktora" podle žáků právě v jeho vlastnostech a rysech osobnosti (Vencovská et al., 2015).

Mezi zdroje s povahou expertní analýzy podle výše uvedené kategorizace (Lepič \& Koucký, 2012), se kterými můžeme pracovat při charakteristice instruktora praktického vyučování a tedy i při identifikaci jeho kompetencí, patří i inspekční zprávy (Česká školní inspekce, 2020). V řadě $z$ nich můžeme najít charakteristiku instruktorů v dané odborné škole. Základní charakteristiky a kompetence instruktora praktického vyučování zmiňované $\mathrm{v}$ inspekčních zprávách se velice často shodují. Můžeme zde pracovat s konstatováním, že instruktoři jsou zkušení pracovníci, kteří jsou vyučeni v daném oboru a mají odpovídající odbornou praxi. Jejich odborné vzdělání bývá v některých případech doplněno studiem pedagogického minima. Pro vlastní průběh výukových jednotek na provozních pracovištích jsou podle inspekční zprávy rozhodující zejména odborné znalosti a organizační schopnosti instruktorů. Zpráva České školní inspekce na př́kladu inspekční činnosti v jedné ze škol odborného vzdělávání poukazuje na to, že individuální prrístup vede žáky $\mathrm{k}$ získávání a upevňování praktických dovedností a návyků, manuální zručnosti, pečlivosti a samostatného rozhodování (Česká školní inspekce, 2004).

$\mathrm{V}$ předložené studii není dostatek prostoru pro komparaci zahraničních zkušeností v oblasti vzdělávání instruktorů, nicméně jeden ze zdrojů využijeme při identifikaci kompetencí a vymezení indikátorů pro instruktora praktického vyučování. Jde o databázi $\mathrm{O}^{*} \mathrm{NET}$ Resource Center využívanou v USA, která je primárním zdrojem pro získávání informací o povolání $\left(\mathrm{O}^{*} \mathrm{NET}\right.$, 2020). V databázi je dostupných přes 1000 povolání obsahujících specifické deskriptory prŕslušných povolání. Instruktor se zde objevuje ve více rolích, našemu tématu a zaměření prŕspěvku odpovídá nejvíce povolání „učitel odborného vzdělávání“. V kontextu českého odborného vzdělávání jde sice o jinou roli (v ČR je rozlišován učitel odborného vzdělávání, který je zaměstnancem školy, a instruktor praktického vyučování, který je zaměstnancem firmy), v popisu deskriptorů tohoto povolání se však databáze věnuje i roli instruktora $\mathrm{v}$ pojetí zde předkládaného příspěvku. Z hlediska pracovní činnosti je podnětné i povolání „koordinátor instruktorů“, který je typický zvláště v ze- 
mích, kde je zaveden systém duálního vzdělávání. ${ }^{4}$

$\mathrm{V}$ kontextu předložené studie je podnětný článek Arifina a kol. (2017) věnovaný modelování kompetencí pro instruktory $\mathrm{v}$ odborném vzdělávání. Pracuje se čtyřmi doménami kompetencí instruktora odborného vzdělávání: učitelské kompetence, odborné kompetence, komunikační kompetence a osobnostní kompetence. $\mathrm{V}$ rámci identifikovaných oblastí kompetencí pracujeme $\mathrm{v}$ tabulce $1 \mathrm{~s}$ kompetencemi odbornými, pedagogickými a osobnostními. Tyto tři kategorie byly sestaveny na základě seskupení jednotlivých indikátorů identifikovaných při deskripci a analýze role instruktora praktického vyučování.

\section{DALŠí VZDĚLÁVÁNÍ INSTRUKTORŮ PRAKTICKÉHO VYUČOVÁNÍ}

Pro vymezení indikátorů pro identifikaci kompetencí instruktora praktického vyučování považujeme za podstatné využít i informace získané od realizátorů kurzů pro instruktory praktického vyučování. Primárním zdrojem zde jsou především výstupy z již zmíněného projektu Pospolu. Součástí projektu byla i prŕíprava a rea- lizace kurzu pro instruktora praktického vyučování v celkovém rozsahu 40 hodin (oveřen byl na 21 účastnících). Pro potřeby naší studie využijeme zejména výstupy z rozhovorů se zástupci škol, které kurzy pořádaly (NUV, 2015) a rovněž popisy a hodnocení jednotlivých instruktorů zapojených do projektu (Vencovská et al., 2015). Další informace pocházejí ze zpráv a analýz získaných od dalších poskytovatelů (př́p. autorizovaných osob) kurzu pro instruktora praktického vyučování (Kaňáková, 2019).

Podle Kaňákové (2019) některé školy i firmy pocitují kvưli zvýšení kvality a relevance obsahu praktického vyučování potřebu instruktory proškolit. Vètšinou se však jedná o krátké kurzy zaměrené na seznámení s bezpečností a ochranou zdraví při práci a povinnostmi instruktora, někdy se v kurzech, zejména pokud do jejich prrípravy vstupují školy, objevují také základy pedagogiky a psychologie.

Instruktor praktického vyučování je od roku 2017 součástí národní soustavy kvalifikací (NSK, 2020) a tento standard je vytvořen v souladu se zákonem č. 179/2006 Sb., o ověřování a uznávání výsledků dalšího vzdělávání. Původní název kvalifikace byl Instruktor u poskytovatele praktického vyučování (platný dle NSK do 14. 3. 2020),

\footnotetext{
$\overline{{ }^{4} \text { Nabízí se zde inspirace zahraničními podobami požadavků kladených na instruktory a např. i komparace }}$ nároků na pozici instruktor v př́padě, že je v dané zemi či firmě/škole uplatňováno duální vzdělávání (inspiraci můžeme hledat z hlediska geografického nejblíže např. v Německu či na Slovensku, ale i v Rakousku, Švýcarsku, Dánsku a dalších zemích). Přehledně tuto tematiku zpracovává zejm. Průcha (2019), řada komparativních analýz je dostupná např. i v rámci databáze Cedefop (2020). V rámci odborného vzdělávání nejsou však v řadě zemí, kde je systém odborného vzdělávání rozvinutý (např. Švédsko, Finsko), stanoveny formální požadavky na instruktora, předpokládá se pouze vyspělá odborná kompetence a delší pracovní zkušenost v daném oboru (např. ve Finsku obvykle nejméně 10 let). Podrobnější rozbor zahraničních zkušeností by přesáhl rozsah předkládaného př́spěvku.
} 
aktuálně platné standardy jsou označené jako Instruktor praktické výuky u zaměstnavatele (platný od 14. 1. 2020). Ve výstupu príspěvku v tabulce 1 je pracováno i s tímto kvalifikačním standardem.

$\mathrm{K}$ roli instruktora praktického vyučování se vyjadřuje i $\mathrm{MPO}$, které ve svém metodickém doporučení (MPO, 2017) zmiňuje nároky kladené na instruktory praktického vyučování, zejména pak na jejich vzdělávání. Konstatuje, že prvek instruktorů praktického vyučování je typický pro země s duálním systémem odborného vzdělávání. V ČR, kde duální systém není v plném rozsahu využíván, by institut instruktorů měl zůstat na dobrovolné bázi, především prostřednictvím zkoušek z profesní kvalifikace Instruktor praktického vyučování. Podle MPO je v České republice podíl praxí ve firmách na celkovém rozsahu odborného vzdělávání relativně malý, a př́padné legislativní povinné požadavky kladené na instruktory by mohly být spíše kontraproduktivní. Stanovení takové povinnosti by mohlo odrazovat zaměstnavatele od zapojování do odborného vzdělávání a př́ípravy. Rovněž zmíněný požadavek na „pedagogické minimum“ zaměstnanců, kteří ve firmách povedou praxe žáků, by měl být řešen dobrovolně, formou absolvování zkoušky z profesní kvalifikace Instruktor praktického vyučování (tamtéž).

$S$ ohledem na cíl našeho príspěvku je podnětná studie Cedefop (2016a) zaměřná na informace o podobě vzdělávání učitelů a instruktorů praktického vyučování ve vybraných zemích EU (země ReferNet ${ }^{5}$, Islandu a Norska). Ze studie vyplývá, že některé země (Belgie, Itálie, Lotyšsko, Slovinsko) mají koordinátory nebo školitele, kteří mohou také zodpovídat za školení instruktorů v podnicích (např. ve Finsku). Nicméně povinné vzdělávání instruktorů není ve zkoumaných zemích vyžadováno. Systém je nastaven tak, že podnikoví instruktoři obvykle musí splňovat počáteční požadavky dř́ve, než začnou učit, takže nejsou povinni následně absolvovat formální vzdělávání. Jejich vzdělávání nad rámec jejich odborné kvalifikace se tak překlápí do systému neformálního vzdělávání a vzdělávání na pracovišti. Základem pro to jsou dostatečně identifikované kompetence pro danou pozici a z nich analyzované vzdělávací potřeby konkrétního instruktora, na které je navázáno nejen vzdělávání pro instruktory, ale pracují s nimi i další personální činnosti $s$ tím související (výběr instruktorů na základě předem splněných kritérií, motivační mechanismy atd.). ${ }^{6}$

Zabýváme-li se problematikou dalšího vzdělávání instruktorů praktického vyučování, neměli bychom opomenout skutečnost, že instruktory $\mathrm{v}$ českém prostředí si $\mathrm{v}$ rámci některých projektů a kurzů školí samotné př́slušné odborné školy (Kaňáková, 2018). To je situace, která není ani v zahraničí př́liš běžná (spíše dochází ke školení instruktora ze strany firmy, ve které je

\footnotetext{
${ }^{5}$ Sít ReferNet byla založena Evropským střediskem pro rozvoj odborného vzdělávání a přípravy (Cedefop).

${ }^{6} \mathrm{~V}$ této souvislosti můžeme zmínit i „Bruggské komuniké o posílené evropské spolupráci v odborném vzdělávání a př́ípravě v období 2011-2020“ (EU, 2010), které bylo přijato ministry školství 33 evropských zemí. Zapojené státy byly vyzvány, aby zvýšily investice do počáteční i další př́pravy učitelů a instruktorů odborného vzdělávání a snažily se o její zkvalitnění nabídkou různých flexibilních forem.
} 
zaměstnán). Podle Kaňákové roste počet škol, které vzdělávání instruktorů pojímají komplexně a ve kterých je součástí jejich smluvního vztahu se spolupracujícími partnery. Řada škol také využívá školení lektorů, které nabízí Národní pedagogický institut (donedávna Národní ústav pro vzdělávání). Tito lektoři pak dále školí přímo instruktory praktického výcviku ve firmách, které se školami spolupracují.

Výstupy z uvedených zdrojů v podobě identifikovaných indikátorů kompetencí instruktora praktického vyučování jsou zpracovány v tabulce 1 .

$\mathrm{V}$ rámci vzdělávání instruktorů praktického vyučování je však i s ohledem na cíl tohoto př́spěvku namístě brát $\mathrm{v}$ potaz také zpětnou vazbu, event. formulované nedostatky či výstupy z evaluace již realizovaného vzdělávání instruktorů praktického vyučování (Kaňáková, 2019; Neužilová, 2018). Mezi nejčastěji formulované výstupy patří zejména problematika místa realizace vzdělávání (realizace ve školních dílnách vs. realizace na pracovišti instruktora, prrístup do konkurenčního prostředí, uvolňování instruktorů z pracovišt apod.).

Př́kladem dobré praxe $\mathrm{v}$ tomto kontextu může být firma Gerresheimer Horšovský Týn spol. s r. o., která spolupracuje se Středním odborným učilištěm Domažlice $\mathrm{v}$ rámci př́pravy žáků a $\mathrm{v}$ rámci této spolupráce hodnotí kritéria kvalitní přípravy žáků pro budoucí povolání ze strany firmy, instruktora i žáků (Vencovská et al., 2015). Škola ve spolupráci s firmou identifikovala trricet indikátorů kvality, které jsou hodnoceny čtyřmi stupni (mimo jiné i s těmito indikátory pracujeme $\mathrm{v}$ tabulce 1 ).

\section{OBLASTI A INDIKÁTORY KOMPETENCÍ INSTRUKTORA \\ PRAKTICKÉHO VYUČOVÁNÍ}

Text uvedený výše naznačuje, že můžeme pracovat $s$ rozličnými zdroji charakterizujícími roli instruktora a také že je v ČR realizované i další vzdělávání pro instruktory (vč. možnosti uznávání kvalifikace v rámci zákona č. 179/2006 Sb.). Za klíčovou v celém procesu ale považujeme fázi identifikace kompetencí pro tuto cílovou skupinu tak, abychom s využitím jejích výstupů, event. $s$ využitím následné analýzy vzdělávacích potřeb, byli schopni ve firmě vhodného instruktora vybrat, př́padně mu nabídnout odpovídající neformální vzdělávání.

V kontextu identifikace kompetencí instruktorů praktického vyučování považujeme za vhodné využít i kategorizaci Mikkonena a kol. (2017), kteří identifikovali v již existujících výzkumech zaměřených na učitele a instruktory tři klíčové kategorie otázek: 1. Jaký druh podpory dostávají žáci/ studenti při svém vzdělávání na pracovišti? 2. Kdo jsou ti, kteří tuto podporu poskytují? 3. Které faktory v určitém typu podpory posilují, nebo naopak brzdí učení na pracovišti? Tyto tři kategorie otázek se prolínají i do indikátorů kompetencí uvedených $\mathrm{v}$ tabulce 1 . Uvedené skupiny otázek skýtají navíc možnost identifikovat kompetence instruktora praktického vyučování a analyzovat jeho vzdělávací potřeby ve všech třech kategoriích podle Lepiče a Kouckého (2012), tzn. v kategorii „názory pracovníků“, „expertní analýzy“ a „šetření u zaměstnavatelü“ ( $v$ tomto př́padě firem i škol). 
Bartoňková, $H$.

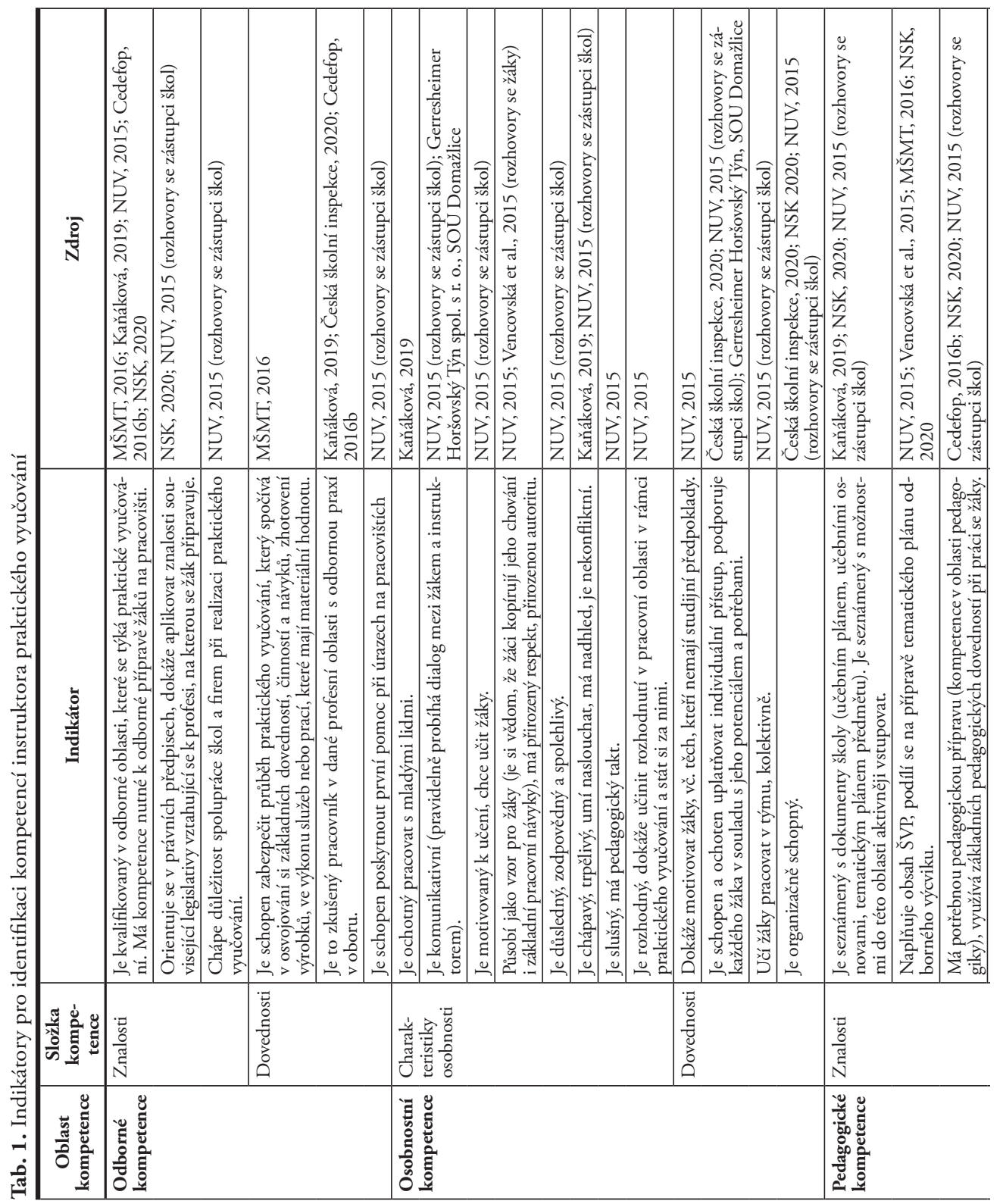




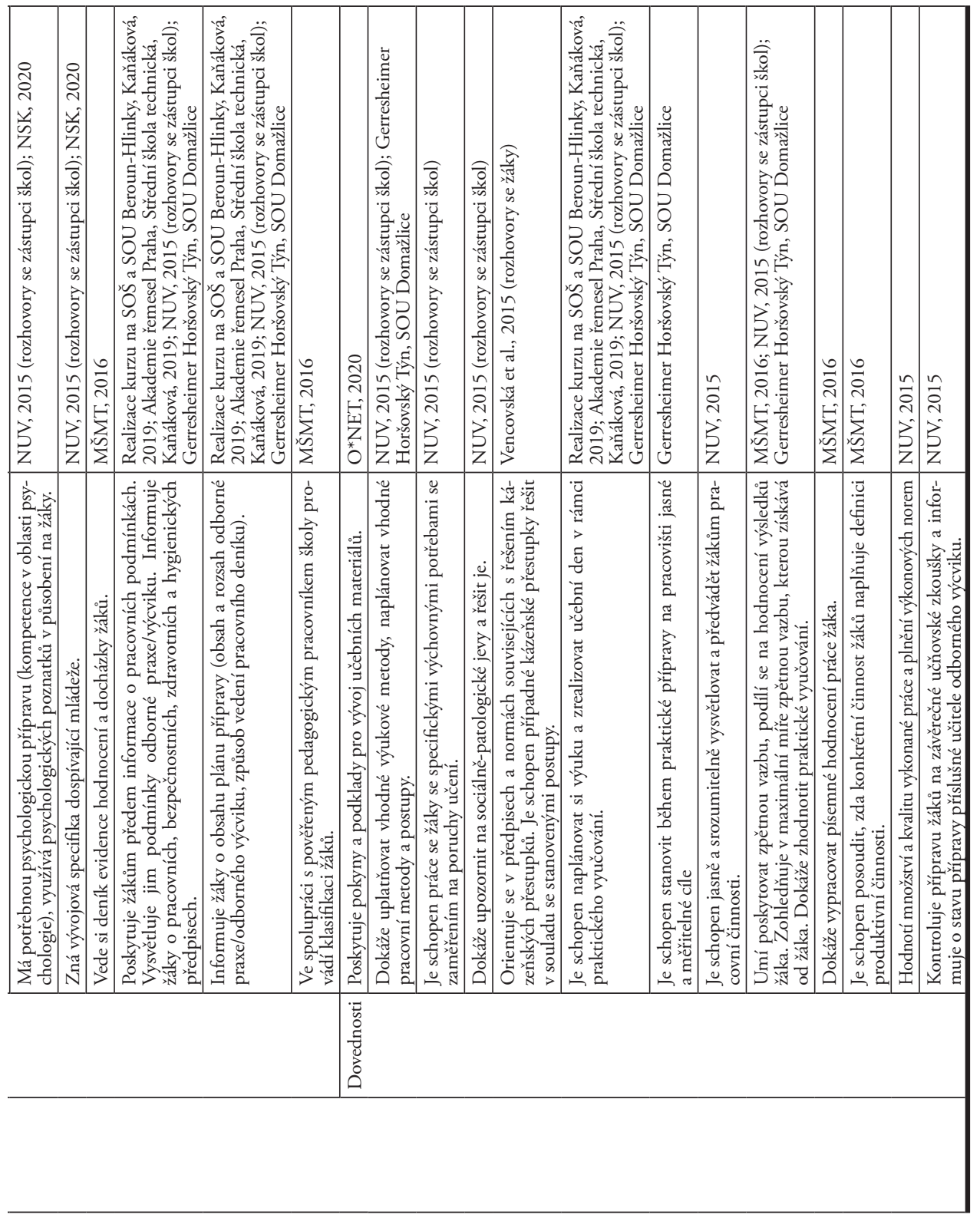


Tabulka 1 je výstupem předloženého př́spěvku. Byla zpracována na základě charakteristiky role instruktora. Bylo zde pracováno se zdroji jak z kategorie expertních analýz, tak $\mathrm{z}$ kategorie údajů od zaměstnavatelů a zpětné vazby od nich (škol i firem). Tabulka představuje výstup sloužící pro zjištování názorů samotných pracovníků (instruktorů). Identifikované indikátory byly $\mathrm{v}$ rámci analytické činnosti tříděny podle kritérií získaných z kontextuálního rámce př́spěvku zaměřeného i na vymezení konceptu kompetence. Indikátory jsou tak rozděleny podle oblastí kompetencí (odborné, pedagogické, osobnostní) a dále tříděny podle struktury kompetencí popsané výše (charakteristiky osobnosti, znalosti, dovednosti). V tabulce je uvedený i př́slušný zdrojový text, ze kterého daný indikátor vychází.
Indikátory kompetencí instruktora praktického vyučování uvedené $\mathrm{v}$ tabulce 1 můžeme měrit, identifikovat míru jejich významnosti pro daný pracovní úkol či možnost jejich zabezpečení pomocí vzdělávání, což je základní předpoklad pro identifikaci vzdělávacích potřeb. Jako velmi vhodná se nám zde jeví metodika navržená Hennessyovou a Hicksovou (2011). Obsahuje dotazník pro analýzu vzdělávacích potřeb, který je primárně navržen a využíván v lékařství pro analýzu potřeb u zdravotnického personálu. Je ale doporučován Světovou zdravotnickou organizací právě pro analýzu vzdělávacích potřeb $\mathrm{v}$ pracovně orientovaném neformálním vzdělávání dospělých (ČSÚ, 2018b). Jeho základem jsou indikátory dané pozice a každý z nich je hodnocený samotným pracovníkem ve čtyřech dimenzích.

Tab. 2. Podklad pro identifikaci kompetencí konkrétním instruktorem ${ }^{7}$

\begin{tabular}{|c|c|c|c|c|c|c|}
\hline \multicolumn{7}{|c|}{ Škála: $1-7\left(1=\right.$ nejnižšíí, $7=$ nejvyššśi $^{8}$} \\
\hline $\begin{array}{l}\text { Oblast } \\
\text { kompetence } \\
\text { (odborné, } \\
\text { pedagogic- } \\
\text { ké, osob- } \\
\text { nostní) }\end{array}$ & $\begin{array}{c}\text { Složka } \\
\text { kompetence } \\
\text { (charak- } \\
\text { teristiky } \\
\text { osobnosti, } \\
\text { znalosti, } \\
\text { dovednosti) }\end{array}$ & Indikátor & $\begin{array}{l}\text { Jak důležitá } \\
\text { je tato ak- } \\
\text { tivita pro } \\
\text { úspěšný vý- } \\
\text { kon v pozici } \\
\text { instruktora } \\
\text { praktického } \\
\text { vyučování }\end{array}$ & $\begin{array}{l}\text { Jak dobře } \\
\text { je úkol } \\
\text { aktuálně } \\
\text { vykonáván }\end{array}$ & $\begin{array}{c}\text { Do jaké } \\
\text { míry je } \\
\text { možné } \\
\text { zlepšit vý- } \\
\text { kon tohoto } \\
\text { úkolu zmè- } \\
\text { nou v dané } \\
\text { organizaci/ } \\
\text { firmě, kde } \\
\text { je praktické } \\
\text { vyučování } \\
\text { realizováno }\end{array}$ & $\begin{array}{l}\text { Do jaké } \\
\text { míry je } \\
\text { možné zlep- } \\
\text { šit výkon } \\
\text { tohoto úko- } \\
\text { lu pomocí } \\
\text { realizace } \\
\text { vzdělávání } \\
\text { určené- } \\
\text { ho pro } \\
\text { instruktory } \\
\text { praktického } \\
\text { vyučování }\end{array}$ \\
\hline
\end{tabular}

\footnotetext{
${ }_{7}^{7}$ Je zde naznačeno pouze záhlaví tabulky, která by následně v dalších řádcích obsahovala oblasti, složky a indikátory kompetencí uvedené $\mathrm{v}$ tabulce 1 .

${ }^{8}$ Škálu v tuto chvíli ponecháváme v rozmezí 1-7 (1 = nejnižší / není důležitá, 7 = nejvyšší / maximálně důležitá) tak, jak ji navrhují Hennessyová a Hicksová (2011).
} 
Výchozím bodem je hodnocení toho, jak důležitá je z pohledu pracovníka daná aktivita pro úspěšný výkon $\mathrm{v}$ dané pozici (část A), druhá část (část B) se týká hodnocení toho, jak dobře je určitá aktivita daným pracovníkem v současné době vykonávána. Dotazník však počítá $s$ tím, že pro to, abychom svou práci vykonávali úspěšně, je třeba mít odpovídající podmínky (př́stup ostatních lidí, kompatibilní pracovní podmínky atd.). Části $\mathrm{C}$ a $\mathrm{D}$ v uvedeném dotazníku se tedy týkají možností zlepšení výkonu bud' změnou v organizaci, nebo pomocí realizace vzdělávání. Vracíme se tak $\mathrm{k}$ již zmíněné komplexitě termínu kompetence, ale i ke zmíněnému konstatování, že výstupy z identifikace kompetencí, event. z analýzy vzdělávacích potřeb můžeme využít nejen pro následné vzdělávání, ale mohou sloužit i jako cenný zdroj pro jiné personální činnosti (nap̌r. pro zde již zmiňovaný výběr instruktora). S využitím metodiky Hennessyové a Hicksové (2011) navrhujeme postup identifikace kompetencí realizovaný přímo konkrétními instruktory (tab. 2)

Budeme-li se držet výše uvedených tří výzkumných postupů při analýze vzdělávacích potřeb (Lepič \& Koucký, 2012), můžeme měření indikátorů s využitím metodiky podle Hennessyové a Hicksové zahrnout do první kategorie (šetření názorů pracovníků). Zaměstnanec (v našem případě instruktor praktického vyučování) by pak posuzoval dané indikátory $\mathrm{v}$ uvedených čtyřech dimenzích na stanovené škále (viz tab. 2).

Druhá kategorie výzkumných postupů (názory expertů) je $\mathrm{v}$ našem návrhu výzkumného designu zahrnuta do fáze formulace indikátorů daných kompetencí (zde je pracováno s legislativními normami a dalšími zdroji expertní povahy). Třetí kategorie výzkumných postupů (požadavky zaměstnavatelů) je v návrhu ve stávající podobě zastoupena údaji získanými z dostupných rozhovorů se zástupci škol a vedení firem a může být samožrejmě dále zpřesňována podle konkrétní podoby a obsahu spolupráce mezi př́ílušnou firmou a školou př̀ realizaci praktického vyučování.

\section{ZÁVĚR}

Hlavním cílem příspěvku bylo vymezit oblasti a indikátory pro identifikaci kompetencí instruktora praktického vyučování ve firmě, tedy $\mathrm{v}$ kontextu podnikového vzdělávání. Jak jsme zde uvedli, instruktor praktického vyučování není pedagogickým pracovníkem $\mathrm{v}$ intencích zákona o pedagogických pracovnících (zákon č. 563/2004 Sb.), do jeho pracovní náplně však spadá řada činností souvisejících s pedagogickým působením. Př́spěvek tak směroval $\mathrm{k}$ vytvoření nástroje pro identifikaci a měrení kompetencí instruktorů praktického vyučování ve firmě. Jeho výstupem jsou identifikované indikátory a oblasti kompetencí pro tuto cílovou skupinu. $\mathrm{V}$ souladu $\mathrm{s}$ vymezením a konceptualizací klíčových konceptů jsou identifikovány tři oblasti kompetencí instruktora praktického vyučování (osobnostní, odborné a pedagogické). Každá z nich je rozpracována do dílčích indikátorů směřujících do jednotlivých složek kompetence 
(charakteristiky osobnosti, znalosti, dovednosti/schopnosti). K sestavení souboru indikátorů jsou využita uvedená teoretická východiska a zdrojové texty zaměrující se na specifikaci role a činnosti instruktora praktického vyučování. $V$ textu je navržen postup pro měření uvedených indikátorů s využitím škály Hennesyové a Hicksové (2011) a s využitím kategorizace výzkumných postupů podle Lepiče a Kouckého (2012), kteří pracují s kategoriemi „názory pracovníkü“, „expertní analýzy“ a ,„̌etření $\mathrm{u}$ zaměstnavatelü “ - v tomto př́ípadě firem i škol.

Za velmi podnětný $\mathrm{v}$ této souvislosti považujeme Průchův apel na aspekty pedagogického (zde i andragogického) výzkumu. Podle Průchy $(2005,2020)$ zůstávají stále nezodpovězeny čtyři klíčové otázky: 1. Podstata - Co to vlastně je, resp. měla by být „využitelnost výzkumu“? 2. Aktéri Kdo využivá, resp. měl by využívat výsledky výzkumu? 3. Účely - K čemu se výzkum využívá, resp. měl by se využívat? 4. Efekty - S jakými účinky se výzkum využívá? Domníváme se, že výzkum v oblasti odborného vzdělávání (a to jak formálního, tak neformálního) má potenciál nalézt odpovědi na tyto otázky (alespoň v rámci svého pole působnosti). Předložený příspěvek by tak mohl sloužit jako výchozí bod pro realizaci výzkumu zaměřeného do oblasti identifikace kompetencí a vzdělávacích potřeb instruktorů praktického vyučování, kteří představují jeden $\mathrm{z}$ významných subjektů odborného vzdělávání nejen v ČR.

\section{Děkuji editorưm čisla a obèma recenzen-} tům za cennou zpètnou vazbu $k$ rukopisu studie.

\section{Literatura}

A Memorandum on Lifelong Learning (2000). Brussels: European Commission. (Online). Dostupné z https://uil.unesco.org

Arifin, M. A., et al. (2017). Addressing competency gaps for vocational instructor through competency modelling. International Journal of Academic Research in Business and Social Sciences, 7(4), 1201-1216.

Bartoňková, H. (2010). Firemní vzdélávání. Praha: Grada.

Beneš, M. (2014). Andragogika. 2. vyd. Praha: Grada.

Cedefop. (2016a). Supporting teachers and trainers. (Online). Dostupné z www.cedefop. europa.eu

Cedefop. (2016b). Professional development for VET teachers and trainers. Briefing note. (Online). Dostupné z www.cedefop.europa.eu

Cedefop. (2020). Vocational education and training in Europe. (Online). Dostupné z www. cedefop.europa.eu

Česká školní inspekce. (2004). Inspekční zpráva. (Online). Dostupné z https://portal.csicr.cz/ Česká školní inspekce. (2020). Registr inspekčních zpráv. (Online). Dostupné z https://portal. csicr.czl

ČSÚ. (2018a). Vzdělávání zaměstnaných osob. Praha: ČSÚ. (Online). Dostupné z www.czso.cz 
ČSÚ. (2018b). Vzděláváni dospèlých v České republice. Praha: ČSÚ. (Online). Dostupné z www.czso.cz

EU. (2010). The Bruges communiqué on enhanced European cooperation in vocational education and training for the period 2011-2020. (Online). Dostupné z www.eqavet.eu

Eurostat. (2020). Early leavers from education and training. (Online). Dostupné z https:// ec.europa.eu/eurostat

Hennessy, D. A., \& Hicks, C. M. (2011). Hennessy-Hicks Training Needs Analysis Questionnaire and Manual. (Online). Dostupné z https://www.who.int/

Kaňáková, M. (2018). Střední školy školí své instruktory praktického vyučování. Učitelské noviny, 27, 36-37.

Kaňáková, M. (2019). Vzdělávání lektorů pro prípravu instruktorů ve firmách. Praha: Národní ústav pro vzdělávání. (Online). Dostupné z https://zamestnanyregion.blob.core.windows. net/

Kubeš, M., Spillerová, D., \& Kurnický, R. (2004). Manažerské kompetence: zpiosobilosti výjimečných manažerü. Praha: Grada.

Lepič, M., \& Koucký, J. (2012). Kvalifikační potřeby trhu práce. Praha: NÚV.

Lucia, A. D., \& Lepsinger, R. (1999). The art and science of competency models. San Francisco: Jossey-Bass.

Maxwell, J. (2012). Qualitative research design: An interactive approach. 3. vyd. London: Sage. Mikkonen, S., et al. (2017). Guiding workplace learning in vocational education and training: A literature review. Empirical Research in Vocational Education and Traininig, 9(9).

MPO. (2017). Metodická doporučení k zapojeni zamèstnavatelů do systémového definováni obsahů středního odborného vzdělávání. (Online). Dostupné z www.mpo.cz

MŠMT. (2016). Doporučeni k zabezpečení jednotného postupu při uzaviráni smlouvy o obsahu, rozsahu a podminkách konáni praktického vyučováni realizovaného na pracovištích fyzických či právnických osob, které maji oprávnèni $k$ činnosti souvisejicí s daným oborem vzdèlání. (Online). Dostupné z www.msmt.cz

Neužilová, M. (2018). Instruktor u poskytovatele praktického vyučování. (Online). Dostupné $\mathrm{z}$ https://www.impulsprokarieru.cz

NSK. (2020). Instruktor praktické výnky u zamèstnavatele. (Online). Dostupné z www.narodnikvalifikace.cz

NUV. (2015). Instruktor praktického vyučování. (Online). Dostupné z www.nuv.cz/pospolu

NUV. (2019). Středni školy vitaji vzděláváni instruktorů praktického vyučování, samy v nèm pomáhají. (Online). Dostupné z www.nuv.cz

O*NET. (2020). O*NET Resource Center. (Online). Dostupné z www.onetcenter.org

Průcha, J. (2005). Český pedagogický výzkum: problém využitelnosti produktů. In J. Vaštatková (ed.), Pedagogický výzkum: Reflexe společenských potřeb a očekáváni. Sborník z XIII. konference $\check{C} A P V$ (s. 11-16). Olomouc: Univerzita Palackého.

Průcha, J. (2019). Odborné školství a odborné vzdělávání. Praha: Wolters Kluwer. 
Průcha, J. (2020). Pedagogický výzkum a využití v praxi - téma pro diskuzi. Pedagogika, 70(1), 97-101.

Průcha, J., \& Veteška, J. (2014). Andragogický slovnik. 2. vyd. Praha: Grada.

Rosenthal, R., \& Jacobson, L. (1992). Pygmalion in the classroom. Wales: Crown House.

Sanghi, S. (2008). The handbook of competency mapping. 2. vyd. Los Angeles: Sage.

Spencer, L. M., \& Spencer, S. M. (1993). Competence at work. New York: John Wiley \& Sons.

Starý, K., Laufková, V., et al. (2016). Formativní hodnocení ve výuce. Praha: Portál.

Švaříček, R., Šed’ová, K., et al. (2007). Kvalitativní výzkum v pedagogických védách. Praha: Portál.

Tight, M. (2003). Key concepts in adult education and training. 2. vyd. London: Routledge.

Tureckiová, M., \& Veteška, J. (2011). Význam kvalifikací a kompetencí v profesním vzdělávání dospělých. In T. Janík, P. Knecht \& S. Šebestová (Eds.), Smišený design v pedagogickém výzkumu: Sbornik prìspèvkì z 19. výroční konference ČAPV (s. 62-67). Brno: Masarykova univerzita.

Vencovská, T., Kaňáková, M., \& Bečvářová, L. (2015). Instruktor. Praha: Národní ústav pro vzdělávání. (Online). Dostupné z www.nuv.cz/pospolu

Veteška, J. (2016). Přehled andragogiky. Praha: Portál.

Vyhláška č. 13/2005 Sb., o středním vzdělávání a vzdělávání v konzervatoři.

Vyhláška č. 374/2006 Sb., kterou se mění vyhláška č. 13/2005 Sb., o středním vzdělávání a vzdělávání $\mathrm{v}$ konzervatoři.

Zákon č. 179/2006 Sb., o ověřování a uznávání výsledků dalšího vzdělávání.

Zákon č. 563/2004 Sb., o pedagogických pracovnících.

Mgr. Hana Bartoňková, Ph.D.

Univerzita Palackého v Olomouci, Filozofická fakulta, Katedra sociologie, andragogiky a kulturní antropologie; e-mail: hana.bartonkova@upol.cz

\section{BARTOŇKOVÁ, H. Instructor of Vocational Training in the Company: Role and Competences}

The paper focuses on the area of non-formal adult education, specifically on the area of further vocational education. The main goal of the paper is to define areas and indicators for identifying the competencies of an instructor of vocational training in a company, i.e. in the context of corporate education. The basic premise is the fact that an instructor of vocational training is not a pedagogical worker in the legal sense of the term. He is in an employment relationship with the organization in which the professional training takes place. He leads the vocational training of 
pupils who come to the workplace to perform vocational training, and his work includes a number of activities related to pedagogical activities. The paper is processed as a theoretical study. At the end of the paper, on the basis of the processing of available resources for the characteristics and demands placed on the instructor of vocational training, areas and indicators of competencies are identified. The result of the text is the identification of three areas of competence of the instructor of vocational training (personal, professional, and pedagogical), each of which is developed into partial indicators pointing to individual components of competence (personality characteristics, knowledge, and skills). The text proposes a procedure for measuring these indicators using the scale of Hennessy and Hicks (2011) and using the categorization of research procedures according to Lepič and Koucký (2012) and Mikkonen et al. (2017).

Keywords: non-formal adult education, further vocational training, instructor of vocational training, competences 